\title{
Critical Discourse Analysis on the Representation of Muslims in Britain in the Daily Mail Newspaper
}

\author{
Benhaddou Mouna \\ Mohamed the first University \\ al-mouna@hotmail.fr
}

DOI: http://doi.org/ 10.36892/ijlls.v3i3.624

\begin{tabular}{l} 
Received: \\
15/06/2021 \\
\hline Accepted: \\
04/08/2021 \\
\\
\hline Keywords: \\
Discourse \\
analysis,news,media, \\
muslims,neswaper
\end{tabular}

The pervasiveness of mass media has become an inevitable side of our daily life; the ubiquity of the latter has allowed an unprecedented influx of information that is not necessarily value free and objective. News corporations have spread enormously and reached different homes, especially with the advent of technology. There are daily articles released claiming to have the most breaking and exclusive scoops of news that was not covered. Nevertheless, people find themselves overwhelmed and unable to differentiate between what is authentic and what is not. Not only that, but they ostensibly newspaper claim to have an innocent editorial line that matches worldwide media ethics, the truth is certainly a far cry from what is publicized. Every day, covert ideologies are passed through news articles that target specific communities that either tend to vilify it exclude to perpetuate certain clichés and stereotypes about it. So this paper aims to critically analyze an article in the Daily Mail British newspaper which was written on British Muslim minorities, it address the issue of religion in a generalized way using extreme categorization, so as to infiltrate and increase division and animosity in British community. The paper uses a set of critical methods of discourses analysis , as transitivity,passivisation, presupposition and categorization, to uncover hidden and even explicit messages ideologies in the article. The analysis shows how implicit strategies are utilized to display a binary line between US and THEM. The THEM group is synonymous with extremism, irrationality and oppression against women whereas US is portrayed as a group serving justice and eradicate fanaticism and radicalism

\section{INTRODUCTION}

Throughout the years media has always pretended to play a major role to mirror what people think, believe, or reject. However, the latter does not suffice neither match up with media's general ideological patterns of a certain group, instead it is the source from which different and fast-growing paradigms stem from, that are daily being redefined manipulated and magnified to a certain extent. Newspapers are believed to be the source of knowledge among people, they claim to be truthful to reconstruct stories about specific communities, such as Muslims who are being attacked obliquely each day by western media. Hence, in order for us to unveil the hidden agendas dispersed everywhere, an efficient tool should be 
used to help us scrutinize media's discourse. News corporations tend to subtly naturalize discourse and render it innocent to reach a certain purpose. On this basis, discourse analysis has widely been useful to warn and sensitize critical and uncritical readers who could be oblivious of the various and elusive strategies used by news agents.

Discourse analysis in this vein will be used in this essay to shed light on the ideological insinuations in articles, and expose the intended meanings concealed behind words. The present paper deals with both theoretical and practical sides. The first part covers the issues of discourse analysis in general including its definitions and main scholars, who contributed in the development of the latter. Also the issue of language and news will be briefly covered, then a set of analytical tools used by linguistic analysts are discussed such as transitivity, categorization, passivization, collocation, and presupposition. The second part is practical, in which an article of the Daily Mail newspaper will be studied, (though not generally representative of all newspapers) applying some of the linguistic tools used by discourse analysts to show how Muslims minorities in Britain are depicted.

\section{LITERATURE REVIEW}

Before defining Discourse analysis we shall look at the word Discourse which is an elusive term that has a complex history. It is used in a range of different ways by different theorists. Originally it denoted 'conversations', 'speech'. As a noun it can mean verbal communication, talk, formal speech or writing on a subject. It can also be a unit of text used by linguists for the analysis of linguistic there is no agreement among linguistics as to the use of the term discourse. Some use it in reference to both text and discourse almost interchangeably, but the former refers to the linguistic product, while the latter implies the entire dynamics of the process (Dakowska, 2001). Consequently, there have been seven criteria proposed by Beaugrande (1981) to match with the term discourse, either a written or a spokentextwhichare:

cohesion/intentionality/acceptability/informativeness/situationality/intersexuality.

Discourse Analysis (henceforth DA) is the study examining the use of language. Zelling Harris was the first modern linguist, who commenced the study of relation of sentences and coined the name 'discourse analysis' (Cook, 1990). DA aims to study and analyze the use of discourse in relation to language as a system of thought, a sheer social practice that includes and non-specific instances of language (Schifrin, 2001). The Analysis of discourse scrutinizes not only the basic level of what is said, but takes into consideration the surrounding social and historical contexts, digging deeply in what is implicitly impaired. For instance, making distinctions between whether a person is described as a 'terrorist' or a ' martyr' and considering the implications of each term. DA was influenced by Foucault, who set the stepping stones for many social theorists his theories have actually led to a specialized variant of discourse analysis, called Foucauldian discourse analysis. In 1972, Foucault wrote "Nothing has any meaning outside of discourse"(p.44), and the point he was trying to make here was that discourse creates a social context and gives meaning to anything that is spoken about.

Initially, it is not to be treated as a separate branch of study but described as crossdisciplined, to which many established disciplines have contributed. As Van Dijk notes:

...discourse analysis for me is essentially multidisciplinary, and involves linguistics, poetics, semiotics, psychology, sociology, anthropology, history, and communication research. What I find crucial though is that precisely because of its multi-faceted nature, this multidisciplinary research should be integrated (2002, p.10).

So, discourse analysis does not have a rigid framework. For instance some discourse analysts are linguists or applied linguists some try to analyze texts in terms of their 
grammatical structures; others draw mainly on conversational analysis and speech act theory. Other discourse analysts search for patterns of language use that may be linked to social or power structure and ideological colorings. Critical Discourse Analysis (henceforth CDA) is another sub-discipline of Discourse Analysis; (CDA) combines linguistic analysis, ideological critique and cognitive psychology. Its aim is to uncover ideological and power relations, and it has mainly been applied for the analysis of political discourse. It also studies strategies used by writers to "naturalize" discourses. CDA was further developed by a group of critical analysts in 1970 (Fowler et. al., 1979; Kress \& Hodge, 1979) that aimed at developing analytical tools to isolate ideology in discourse. Their approach was based on Halliday's Systemic Functional Grammar (1985) which he himself believed that texts are a process and a product which are created, embedded, and interpreted in a specific social context. Hence, he provided three functions for language: ideational (the experience of the speaker) interpersonal (his attitudes about the phenomena) textual (production of text).

\section{MAIN ADVOCATES OF CRITICAL DISCOURSE ANALYSIS}

Halliday's view of language as a "social act" (1985) is central to many of CDA's practitioners such as Fairclough, who defines CDA as: the study of often opaque relationships of causality and determinism between discursive practices, event and text and a wider social and cultural structures, to investigate how such practices are ideologically shaped by relations of power and struggles over power, and their opacity (1995, pp.132-3). He believes that the language is an irreducible part of social life. Fairclough attempts to uncover ideological and power patterns (1989). On this vein he provides a three-dimensional framework for the analysis of text and discourse: 1) the linguistic description 2) the interpretation 3) the explanation of the relationship between discourse and social and cultural reality. Fairclough's (ibid) analysis has gone beyond the "whatness" of the text; there are certain underlying assumptions behind certain selections of, discourse. These assumptions are never value-free and innocent; this leads to the exploration of power relations that exist in the society or community. He believes in a "hidden agenda".

Among CDA practitioners, van Dijk is one of the most often referenced and quoted in critical studies of media discourse, even in studies that do not necessarily fit within the CDA perspective. Van Dijk (1995) essentially perceives discourse analysis as ideology analysis, because according to him, "ideologies are typically, expressed and reproduced in discourse. In this sense, for van Dijk, "ideologies are the overall, abstract mental systems that organize socially shared attitudes" (p. 18). Thus, indirectly influence the personal cognition of group members. Also he draws attention to the mental representations that are often articulated along Us versus Them dimensions, in which speakers of one group will generally tend to present themselves or their own group in positive terms, and other groups in negative terms" (ibid).

Discourse Sociolinguistics is one of the directions in CDA associated with Wodak. She has carried out research on a variety of social issues such as sexism, racism and antiSemitism. Wodak's work on the discourse of anti-Semitism in 1990 led to the development of an approach she termed as the discourse historical method. According to Wodak \& Ludwig (1999), viewing language this way entails three compponents at least. First, discourse "always involves power and ideologies. Second, discourse is always historical, that is, it is connected synchronically and diachronically with other communicative events .The third feature is that of interpretation. According to her readers and listeners, depending on their background knowledge and information and their position, might have different interpretations of the same communicative events (p. 13). Therefore, Wodak \& Ludwig (1999) assert that "THE RIGHT" interpretation does not exist.

\subsection{Language and the News}


Language inevitably slants the presentation of content, or more radically that language constructs the world it denotes according to its own socially manufactured structures. It is agreed that a novel constructs fiction similarly as the discourse of news that produces fabricated events there are ideological bias introduced in the process of the representation; readers are instructed obliquely on how to perceive the values imposed via language in the news (Fowler 1991). Hence, Fowler claims that reality does not exist naturally, but it is created with social convention. News is simply a social practice that does not produce event purely but rather shapes them in accordance with patterns found in social structures; another point is that all linguistic options made in the discourse of the press are from a certain agenda, so the style adopted by newspapers as register ,or field, is an attempt to bridge the discursive gap between an individual and the institution. Once the linguistic signs of a newspaper has been accepted by readership, then the imposition of values becomes painless and an unconscious process. So Fowler tries to address any critical reader of the press and urges him to evade the imposition of social paradigms that does not make knowledge of the represented world and he concludes by saying that the unmediated purity of events will remain always beyond the common reader's power (ibid).

\section{ANALYTICAL TOOLS TO DISCERN DISCOURSE}

Because of the powerful role of language to reproduce knowledge, it could be quite elusive to decipher it. Some words and some contexts have more power than others since not all words or contexts are equal, nor are all words and contexts loaded with the same semantic weight (Thompson, 1991) .The power by which individuals use language to shape discourse may change depending on who creates an utterance and under what circumstances an utterance is employed. Hence, we need analytical devices to decipher language.

Transitivity is concerned with the representation of the mental picture that a writer has of the world; it involves the transmission of ideas and therefore belongs to the ideational function (Halliday, 1985). According to Halliday, "transitivity is the set of options whereby the speaker encodes his experience of the process of the external world, and of the internal world of his own consciousness, together with the participants in these processes and their attendant circumstances (...)". Transitivity thus focuses on how a writer represents who acts (who is agent) and who is acted upon (who is affected by the actions of others). Transitivity refers to three basic elements. The first is a process (material relational and mental verbal); this process is combined with one or more nouns or noun phrases which indicate secondly the participants in the event or the state of affairs. The process may also be accompanied by one or more circumstances which are the third element.

Categorization focuses on studying how people categorize each other in everyday conversations or in written materials, in this case newspapers, which often tries to divide people into relational pairs according to the person's perception. Hence, it is the production of Terms, Definitions and Illustrations for referring to persons that categorize them, and in so doing convey evaluation (Schegloff, 2007) for instance, calling an 18-year-old who is stealing "a boy" or "a man," a "shoplifter," or a "thief." Or more conveniently to our case study, categorization is illustrated when a group uses the polarization of US versus THEM, as a way to show the cleavage, according to the speakers'perception, in social,political or cultural division if there is any.

Nominalization: Halliday states that nominalization is a tool "whereby any element or group of elements is made to function as a nominal group in the clause" (1994, p. 41), in other words it is the process of producing a noun from another part of speech. For example, the verb evaluate can be used in the phrase "we will evaluate the data" or nominalized in the phrase "an evaluation will occur. Passivization similarly transforms the subject of a sentence from an active agent to an object. For example, "John moved the table" is constructed such that John is the subject and the performer of the actions whereas the sentence, "The table was 
moved by John" is constructed such that John is an object. So, Nouns and noun phrases are assumed to be nominalized from underlying verbal processes, or actions turned into objects. Similarly, a consistent, 'systematic' use of nominalization in a text could be used as an ideological agenda or motivation of the author.

Collocation on the other hand is the existence of a sequence of words that co-occur more often than would be expected by chance, e.g., disease terms (plague, epidemic, disease) that occur near the word "immigrant." Obviously, it is a method utilized by authors or scipt writers to associate subtly certain features or events that happen simulteously with the existence of a group of people eluding to the idea that they could be the reason behind these occurences

Presupposition: what is taken by the hearer as common sense ,these are words or phrases that assume the truth of the statements in which they are found. For example, in the sentence, "President Clinton's liberal views are not popular with many Congressional Republicans," it is presupposed that President Clinton is liberal (Huckin, 2002).

Inferring from the previously discussed tools and methods used in discourse anlysis to decode the hidden ideologies, the following section will focus on the analysis of an article in one of the Btitish newpapers. The analysis tends to apply the different practical methods to discern and deconstruct the value laden discourse in the article.

\section{Application of Discourse analysis on Daily Mail newspaper:}

"The British child brides: Muslim mosque leaders agree to marry girl of $12 .$. So long as parents don't tell anyone"

Immigration and the presence of "different" communities in Britain have been the Subject matter of many studies, and debates from various angles within the last few decades. Hence, the western media having access to mass audience has always attempted to draw itself apart from the incoming flows of minorities. It enhances its hegemonic majority through casting out the constructed out -groups via discriminatory discourses that are replete with hidden ideologies aiming to mould or reinforce existing cultural social and mainly religious paradigms of minorities. British newspapers have widely targeted Muslim minorities in particular, in which they associate and incorporats the elements of difference, deviance, perceived threat and above all religious extremism plus fanatic acts in articles that are intended to leave implicitly repulsive effects on the readership. Therefore, this part is devoted to a critical analysis of a British article entitled "The British child brides: Muslim mosque leaders agree to marry girl of $12 \ldots$ So long as parents don't tell anyone" in the daily Mail newspaper. As the headline implies, the representation of Islam in the latter is quite negative that denotes inhumane activities by Muslim leaders upon children. To further comprehend the hidden ideologies inculcated in the article we shall use linguistic device to extract them.

Transitivity analysis may give fresh light on the interpretation of the text through a focus on the kind of processes and participants involved here the following is a table of arrangement of process, participants that will simplify in revealing the content of discourse.

\begin{tabular}{|l|l|l|}
\hline \multicolumn{1}{|c|}{ example } & \multicolumn{1}{c|}{ process } & \multicolumn{1}{c|}{ Participants } \\
\hline $\begin{array}{l}\text { Two imams officiate wedding } \\
\text { of underage girl to a man in his } \\
\text { twenties }\end{array}$ & Material/ officiate & $\begin{array}{l}\text { Underage girl /AFFECTED } \\
\text { Man in his twenties/ } \\
\text { BENEFECIARY }\end{array}$ \\
\hline $\begin{array}{l}\text { Islamic law allows such } \\
\text { couples to have sex after } \\
\text { marriage }\end{array}$ & Material /Allow & Such couples /AFFECTED \\
\hline $\begin{array}{l}\text { More than 1,000 of the 8,000 } \\
\text { forced marriages involve girls } \\
\text { of } 15 \text { or under }\end{array}$ & Material/ force involve force & $\begin{array}{l}\text { Girls of 15 or under/ } \\
\text { AFFECTED }\end{array}$ \\
\hline
\end{tabular}




\begin{tabular}{|l|l|l|}
\hline $\begin{array}{l}\text { one case last year allegedly } \\
\text { involving a girl of five. }\end{array}$ & Material/ nonfinite involve & a girl of five/AFEECTED \\
\hline $\begin{array}{l}\text { Another retired Imam was } \\
\text { happy to marry a 12-year-old } \\
\text { girl but only if her parents told } \\
\text { no-one about it }\end{array}$ & $\begin{array}{l}\text { Relational /was happy (Value) } \\
\text { Material to marry } \\
\text { Verbal told }\end{array}$ & $\begin{array}{l}\text { Imam token / } \\
\text { Imam actor } \\
\text { 12-year-old girl AFFECTED } \\
\text { Parents SAYER/no-one } \\
\text { RECIEVER }\end{array}$ \\
\hline $\begin{array}{l}\text { The Forced Marriage Unit, } \\
\text { dealt with1,468 cases involving } \\
\text { children under the age of 15 }\end{array}$ & Material/ deal & $\begin{array}{l}\text { The Forced Marriage Unit, } \\
\text { ACTOR } \\
\text { children underage/ AFFECT }\end{array}$ \\
\hline $\begin{array}{l}\text { Imam reportedly agreed to carry } \\
\text { out the ceremony after evening } \\
\text { prayers on Wednesday. }\end{array}$ & $\begin{array}{l}\text { Imam /ACTOR. The ceremony } \\
\text { /Beneficiary } \\
\text { After evening prayers on } \\
\text { Wednesday. CIRCUMSTANCE }\end{array}$ \\
\hline $\begin{array}{l}\text { Campaigners argue that children } \\
\text { can't decide whether they want } \\
\text { to be married (posed by model) }\end{array}$ & Verbal argue & $\begin{array}{l}\text { Campaigners /SAYER / } \\
\text { that children can't } \\
\text { decide/VERBIAGE }\end{array}$ \\
\hline $\begin{array}{l}\text { the Home Office confirms that } \\
\text { such ceremonies will be } \\
\text { examined in the Government } \\
\text { ceremonies will be examined in } \\
\text { the Government VERBIAGE }\end{array}$ \\
\hline
\end{tabular}

The transitivity patterns in the article display how the field of situation is constructed. As observed, most of the material processes produced are associated with Muslim community are ostensibly intending to be involved in the act of marrying under aged girls. These processes (such as allowing, marrying; forcing, officiate) are negatively constructed, to fulfill unaccepted and out of norms activities of the Muslim community living in Britain. This method used to reinforce the stereotypical idea of force that could be well seen in the distribution of the participants. The article insinuates that Muslim parents and imams are often the actors that cause harm and trigger suffering to the innocent girls, constantly shown as affected by the act of marriage by force. On the other hand, the British people are implicitly and explicitly, shown to be positively involved in processes (verbal and material) that tend to stand for the case of Muslim girls, seriously, defending them out of humane duty done by the British to save them from their own ethnic group. Ironically, we do not notice any positive process associated to a Muslim agent that tends to speak for or defend these girls. This makes us infer that there is the impossibility of relating Muslims to be advocates of human rights. Hence, based on the all previous odds, claims of Muslims being rightful have been muffled and repressed in the article, to merely show them as oppressors and bring to the light British as being agents of peace and freedom.

Passivization along with nominalization have the same important ideological functions, such as deleting agency and reifying processes, Fowler et al(1979) demonstrated that choosing noun phrases or passive forms over active ones is often ideologically charges the latter carries several ideological feature such as deleting the agent, reifying, positing concepts or preserving unequal power(Fowler,1991). In the article there are several examples used to insinuate or serve a specific purpose, such as the phrase: "the girl is coerced or forced into marriage" there is less information accompanied with an agentless statement. Thus, the act is being stressed on and enlarged; the word 'forcing' itself takes on unconsciously a magnified shape inside the reader's mind and increases the level of atrocity. Hence, the absent becomes ridiculed and marginalized. Another example that shows the imbalance of relation is " a husband can be prosecuted for rape if he has sex with an underage girl"; ostensibly the sentence seems to ease up the previous effects however there are points that should be discusses, such as the deletion of agent that connotes the underestimation and 
invalidity of Islamic law. Whereas most sentences concerned with British law is used in active voice, which again shows the ideology of asserting the inequality of powers.

\section{Categorization and presupposition}

Vocabulary is a very influential method, as it fulfills the ideational function of Halliday's model (1985); these linguistic aspects of language such as categorization are manipulated by writers to facilitate abuses or moulds specific targets according to the desired agenda. Thus I will scrutinize some of the vocabulary in the article to decrypt the implicit meaning through the analysis of the vocabulary. It can be inferred that the Muslim community is mostly referred to in terms of religious categories mainly rather than names, such as "Imam, Muslim Council clerics, mosque leaders". The emphasis is not merely on the action which is supposed to be the pivotal point in the article. Instead, these men of religion logically, representing Islam are given a great deal of space within the article to serve in appropriating the underage marriages to Islamic religion. Besides, there is an extensive use of words like "illegal, secrecy, force, abuse coerce; unacceptable" which are scattered along the article, to give the impression that Muslims are homogenized as backward or deviant. They are shown to be involved in out of law activities do not match with the western mainstream that are given labels as "The Forced Marriage Unit, Home office, campaigners". Hence, there is an embedded comparison between both groups. Muslim are depicted as irrational and abusive groups, whereas the British are shown to be law agents that oppose radicalism unethical and inhumane acts.

Presupposition as illustrated in the theoretical part tends to assume a common sense the truth of statements as found in following sentence: "Under sharia there is no problem. She should see her first sign of puberty at the house of her husband". The latter presupposes that Islam is associated with fanaticism and moral decadence since it is represented to encourage child marriages, and abuses young girls who have not reached age of maturity yet. Hence, being exploited by Islamic community, it supports also the idea of the oppressive patriarchal system which monopolizes women and constrains their freedom. Second, through analysis of presupposition we can see how stereotypes are widely being naturalized and maintained in the press through this sentence: "He explained how the Prophet Muhammad had married a seven-year-old girl before adding: 'We are his followers", the sentence even if putting things out of context presupposes that the prophet PBUH was the founder of child abuse and the main culprit to what is being done by Muslims; of hideous acts because they are incited to follow his steps. Therefore, the former analytical tools help us expose the covert meanings, in the article that are meant to perpetuate falsely the stereotypes associated to Islamic religion.

\section{CONCLUSION}

In brief, the paper demonstrates how discourse analysis is a very effective method to detect western ideologies embedded in news discourse that is deemed by laymen as quite objective and value free in all perspectives, the hypothesis that has been rebutted in the present paper showing that newspaers have implicit messages underlying certain agendas. The subjectivity of newspaper is plain, and it is replete with different stereotypical loads that slant and modalize Muslim representation. The latter is done to construct persuasively new and confirm already present ideologies, covertly presented to serve a certain editorial line, and enhance the western hegemony so as to make a distinction between US and THEM. Speakers of one group will generally tend to present themselves or their own group in positive terms, and other groups are described in negative terms. This is manifest overtly in the article where the term Islam is often synonymous with extremism, irrationality and oppression against women that succumb to the patriarchal power imposed on them unwillingly through segregation or other forcible acts such as marriage. Hence, the latter is highly enlarged and meticulously knitted via language to help associate Muslim with backwardness insensibility. In contrast, British are demonstrated in the article as constantly 
struggling to serve justice and eradicate fanaticism and radicalism as a result, compatible with human rights and freedom. Thus, the ideology of the article serves to construct a general collective rejection and repulsion against Muslims, who are deemed as repressive and stuck in the past; they are portrayed as a contagious phenomenon that should be deconstructed and purged from its essence so as not to infect the other communities. Finally, I deduce through the application of discourse analysis on the British newspaper that media is never value free, it constantly works to serve and sustain a certain ideology in its social context

\section{REFERENCES}

Alba-Juez, L. (2009). Perspectives on Discourse Analysis: Theory and Practice.Cambridge Scholars Publishing.

Beaugrande, R.(1981) Wolfgang Dressler. Introduction to Text Linguistics. London: Longman.

Cook,G.(1990).Disourse. Oxford: Oxford University Press

Fairclough, N. (1989). Language and Power. London: Longman.

Fairlough, N. (1995) Critical Discourse Analysis. London, Longman.

Fowler, R., Hodge, B., Kress, G. and Trew, T. (1979) Language and Social Control. London .Routledge.

Fowler, R. (1991). Language in the News. Discourse and Ideology in the Press. London:Routledge.

Foucault, M., (1972). The Archaeology of Knowledge. London: Routledge.

Hackin, Thomas.(2002). In Discourse Studies in Composition. ed. E. Barton and G. Stygall. Hampton.

Halliday, M. A. K. (1985) An Introduction to Functional Grammar. London, Edward Arnold.

Halliday, M.A.K., \& Hasan,R. (1985). Language, context, and text: Aspects of language in a social-semiotic perspective. Oxford: Oxford University Press. James Paul Gee Discourse Analysis Theory and Method .First published 1999: Routledge

Karen, Tracy. (2011). Critical Discourse Analysis and Communication Scholarship Recovering Old Connections, Envisioning New Ones .Routledge

Schoffrin,.D. (2001). Handbook of discourse analysis. Heidi Hamilton,. Deborah Tannen(eds). Oxford: Basil Blackwell.

Van Dijk, T.A. (1998). Ideology: A Multidisciplinary Approach.London. Sage.

Van Dijk, T.A. (1996). Discourse, Opinions and Ideologies. In Christina Schaffner \& Helen Kelly-Holmes (eds.) Discourse and Ideologies. Clevedon: Multilingual matters Ltd, 1996. 7-37

Van Dijk, T.A., ed. (1985). Handbook of Discourse Analysis, 4 vols. London: Academic Press.

Wodak, R., ed. (1989) Language, Power and Ideology. Amsterdam: Benjamins. 
Wodak, R. (1985). "The interaction between judge and defendant". In T.A. van Dijk (ed) Handbook of Discourse Analysis. Vol. 4. Discourse Analysis in Society. London: Academic Press.

\section{Electronic references:}

- What is Discourse Analysis: from www.tlumacznia-angielski.info/ retrieved on 11.12 .12

- Principles of Critical Analysis; from www.discourses.org/ retrieved on 01.12.12

- The language of Discourse Analysis; from www.academia.edu retrieved on 25.12.12

\section{AUTHOR'S BIO}

Benhaddou Mouna, a PhD researcher and a teacher of English. Currently enrolled in PhD program at the University of Mohammed I in Oujda in 'the Space, Culture and Communication research unit'. She had several contributions and participated in various conferences related to research in higher education, I am also interested in study scopes of identity, cultural and migration studies. 